\title{
DELIVERY SERVICE PUSTAKAWAN DI ERA NEW NORMAL
}

\author{
Erna Fitri Widayati \\ Universitas Jenderal Achmad Yani Yogyakarta \\ Email : erna.fitri@unjaya.ac.id, efwidayati@gmail.com \\ Pariyanti \\ Universitas Jenderal Achmad Yani Yogyakarta \\ Email : pariyanti19@gmail.com
}

\begin{abstract}
The COVID-19 pandemic has a major impact on various sectors of life including libraries, forcing people to adapt to new habits or new-normal. Delivery service is an information delivery service, where the product is in the form of information needed by users, using technology as a medium of contact. The products served consist of physical and digital information products. The research method uses literature studies, analysis of previous research, and direct observation. The results of the author's analysis show that during the pandemic, the library could not perform its duties and functions optimally due to the lack of resources and the limited capacity of the library. Libraries are required to transform from physical to digital services. In the new normal era, librarians play an active role in providing information that can be accessed remotely, creating digital content, promoting social media-based libraries, providing online services, developing digital libraries, optimizing collaboration between libraries, providing alternative reference sources that can be accessed for free, making innovative information delivery services. The conclusion is that the delivery service can be an alternative solution to optimize library services and the active role of librarians, thereby increasing the positive image of the library in the future.
\end{abstract}

Keywords: delivery service, new normal, library service.

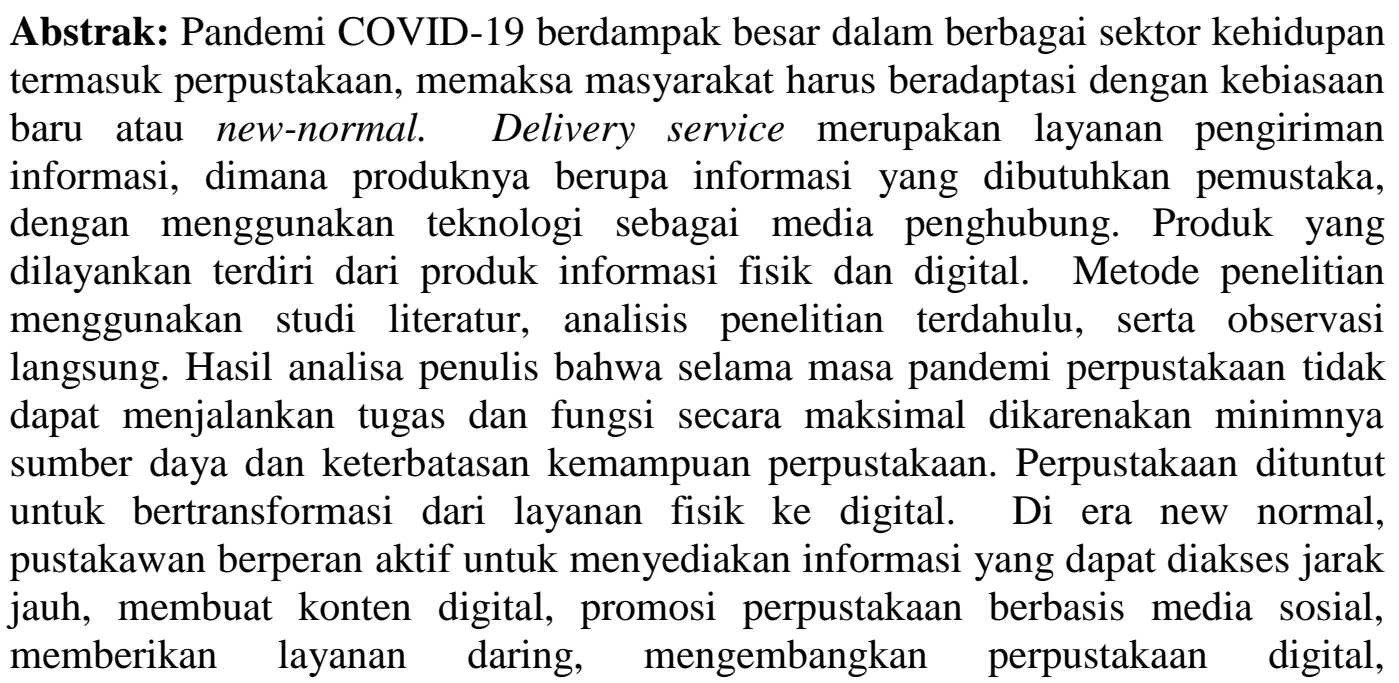


mengoptimalkan kerjasama antar perpustakaan, memberikan sumber referensi alternatif yang dapat diakses secara gratis, membuat inovasi delivery service informasi. Kesimpulan yang didapatkan bahwasannya delivery service dapat menjadi solusi alternatif untuk mengoptimalkan layanan perpustakaan dan peran aktif pustakawan, sehingga meningkatkan citra positif perpustakaan di masa yang akan datang.

Kata Kunci: delivery service, new normal, layanan perpustakaan.

\section{PENDAHULUAN}

Awal tahun 2020, World Health Organization (WHO) mengumumkan temuan virus baru berjenis Coronavirus Disease (COVID-19) yang berasal dari Wuhan, China dan telah mewabah ke sebagian besar negara di dunia. Pandemi COVID-19 berdampak besar dalam berbagai sektor kehidupan masyarakat, sosialekonomi, pendidikan, hingga penurunan kondisi kesehatan yang berakibat kematian sebagian besar manusia di seluruh dunia, tak terkecuali Indonesia. Data dari WHO pada 16 Agustus 2020 melalui laman https://covid19.who.int/ dilaporkan terkonfirmasi positif COVID-19 sebanyak 21.260.760 jiwa termasuk diantaranya terdapat kasus kematian sebesar 761.018 jiwa bahkan kemungkinan mengalami penambahan ${ }^{1}$. Besarnya dampak tersebut memaksa masyarakat untuk merubah tatanan kehidupan masyarakat ke tatanan hidup dengan menerapkan adaptasi kebiasaan baru atau new-normal untuk meminimalisir penyebaran virus COVID-19. Pemerintah Indonesia menghimbau untuk menutup layanan publik, pusat perbelanjaan, tempat wisata, pengurangan kepadatan pekerja di sektor industri, hingga memberlakukan work from home untuk meminimalisir penyebaran virus tersebut.

Perpustakaan sebagai salah satu akses layanan publik tidak dapat menjalankan peran dan fungsi secara maksimal. Selama masa pandemi COVID19 banyak perpustakaan menutup akses layanaan secara fisik dan membatasi jumlah kunjungan dengan tetap menerapkan protokol kesehatan. Pemberlakuan physical distancing diikuti pemberlakuan bekerja dari rumah atau WFH membuat layanan perpustakaan tidak dapat berjalan secara maksimal, sehingga perpustakaan dituntut untuk berinovasi dan bertransformasi dari layanan fisik ke

${ }^{1}$ WHO, "WHO Coronavirus Disease (COVID-19) Dashboard," https://covid19.who.int/, 2020. 
layanan digital untuk memenuhi kebutuhan pemustaka. Perpustakaan dapat menyediakan layanan berbasis online, sehingga dapat menjangkau seluruh pengguna perpustakaan terdampak COVID-19.

Perpustakaan bertugas untuk menghimpun, mengelola, memberdayakan dan memberikan layanan informasi kepada pemustaka, sehingga pustakawan dituntut untuk berperan aktif menyajikan dan melayankan informasi secara cepat, tepat, akurat berbasis teknologi informasi. Pustakawan dapat mengoptimalkan pemanfaatan sumber informasi berbasis online untuk memenuhi kebutuhan pemustaka selama masa pandemi COVID-19 masih berlangsung. Peran aktif pustakawan dapat dilakukan dengan memberikan dukungan secara virtual menggunakan sarana teknologi informasi, seperti program literasi informasi, seminar/pelatihan menggunakan aplikasi video komunikasi virtual, pemanfaatan e-resources, serta menyajikan informasi yang up-to-date melalui media sosial. Tidak semua perpustakaan memiliki akses langganan sumber referensi digital maupun memiliki perpustakaan digital, sehingga hal tersebut menjadi kendala akses informasi pemustaka sekaligus tantangan tersendiri bagi pustakawan untuk berinovasi dalam layanan pengguna.

Berdasarkan uraian diatas, penelitian ini hendak membahas tentang peran aktif pustakawan, layanan perpustakaan, dan delivery service informasi perpustakaan di era new normal.

\section{METODE PENELITIAN}

Penelitian ini menggunakan metode studi literatur, menganalisa beberapa publikasi penelitian serta observasi langsung terhadap langkah apa saja yang telah dilaksanakan perpustakaan selama pandemi COVID-19 berlangsung.

\section{KAJIAN TEORI}

Perpustakaan sebagai pengelola dan penyedia informasi kepada pemustaka, dituntut untuk melayankan informasi secara cepat, tepat, akurat, sehingga diperlukan tenaga perpustakaan yang profesional. Tenaga perpustakaan atau disebut pustakawan merupakan seorang yang bertugas melaksanakan 
Erna Fitri Widayati, Pariyanti, Delivery Service Pustakawan Di Era New ...

kegiatan di perpustakaan mulai dari mengumpulkan, mengolah, merawat, melestarikan serta menyajikan informasi maupun bahan pustaka kepada pemustaka. Menurut undang-undang no. 43 tahun 2007 tentang Perpustakaan yang menyebutkan bahwa:

"pustakawan adalah seseorang yang memiliki kompetensi yang diperoleh melalui pendidikan dan/atau pelatihan kepustakawanan serta mempunyai tugas dan tanggung jawab untuk melaksanakan pengelolaan dan pelayanan perpustakaan. Tenaga perpustakaan berkewajiban memberikan layanan prima terhadap pemustaka, menciptakan suasana perpustakaan yang kondusif dan memberikan keteladanan dan menjaga nama baik lembaga dan kedudukannya sesuai dengan tugas dan tanggung jawabnya. Sedangkan pengertian pemustaka adalah pengguna perpustakaan, yaitu perseorangan, kelompok orang, masyarakat, atau lembaga yang memanfaatkan fasilitas layanan perpustakaan" 2 .

Informasi merupakan produk yang akan dilayankan kepada pemustaka. Berdasarkan UU RI No. 14 tahun 2008 tentang Keterbukaan Informasi Publik, "Informasi adalah keterangan, pernyataan, gagasan, dan tanda-tanda yang mengandung nilai, makna, dan pesan, baik data, fakta maupun penjelasannya yang dapat dilihat, didengar, dan dibaca yang disajikan dalam berbagai kemasan dan format yang sesuai dengan perkembangan teknologi informasi dan komunikasi secara elektronik ataupun non elektronik"3. Peran pustakawan dalam pelayanan informasi adalah sebagai ujung tombak yang bertanggung jawab dalam menyampaikan informasi tersebut agar dapat diterima dan dipahami serta relevan dengan kebutuhan pemustaka.

Purwono menjelaskan tanggung jawab seorang pustakawan profesional yang tidak hanya sebatas melaksanakan kegiatan rutin, namun melakukan kegiatan yang bermutu sehingga hasilnya dapat dipertanggungjawabkan melalui prosedur kerja yang benar ${ }^{4}$. Dalam pelaksanaannya, pustakawan melakukan kegiatan perpustakaan bukan untuk kepentingan pribadi, namun untuk kepentingan pemustaka. Sehingga untuk penjalankan perannya, seorang

\footnotetext{
${ }^{2}$ Indonesia, "Undang-Undang Republik Indonesia Nomor 43 Tahun 2007 Tentang Perpustakaan" (2007).

${ }^{3}$ Kementerian Komunikasi dan Informatika RI, “Undang-Undang Republik Indonesia Nomor 14 Tahun 2008 Tentang Keterbukaan Informasi Publik" (2008).

${ }^{4}$ Purwono, Dokumentasi (Yogyakarta: Graha Ilmu, 2010).
} 
pustakawan harus senantiasa mengasah keahliannya untuk meningkatkan kompetensi dan pengetahuan agar dapat memberikan pelayanan yang optimal. Pustakawan dituntut secara terus menerus untuk menyesuaikan kegiatannya sesuai dengan kebutuhan pemustaka. Pustakawan harus senantiasa melihat permasalahan dan peluang yang ada sehingga pustakawan dapat menghadapi setiap gejolak yang muncul di masa depan dengan tetap menunjukkan kualitas profesional yang relevan dengan kebutuhan pemustaka.

Di era pandemi COVID-19 ini peranan teknologi menjadi sangat penting bagi kita dalam mendukung kegiatan sehari-hari untuk dapat dilakukan tanpa keluar rumah seperti berbelanja maupun pembelajaran online. Hal tersebut menjadi kendala bagi pemustaka untuk mengakses sumber informasi tercetak yang ada di perpustakaan, oleh karena itu pustakawan sebagai pengelola informasi di perpustakaan sudah selayaknya ikut menyesuaikan dengan perkembangan yang ada dalam memenuhi kebutuhan pemustaka perpustakaan dengan memanfaatkan teknologi yang ada.

Pustakawan dapat melakukan berbagai inovasi layanan perpustakaan, sehingga kebutuhan informasi pemustaka dapat tercukupi dengan baik. Pustakawan dapat merencanakan strategi pemasaran informasi, membuat inovasi layanan informasi, serta mengimplementasikan pemasaran informasi kepada pemustaka yang membutuhkan. Delivery service inforamsi di era pandemi seperti saat ini, dapat menjadi pemecahan masalah bagi pustakawan untuk meningkatkan layananan kepada pemustaka.

\section{TELAAH PENELITIAN TERDAHULU}

Berdasarkan penelusuran penulis, terdapat beberapa penelitian sejenis yang berhubungan dengan delivery service di perpustakaan, diantaranya:

Penelitian yang dilakukan oleh Rian Dwi Hapsari dkk yang berjudul "Library Service From Home (LSFH): A Library Policy to Fight COVID-19 in Governace Institute of Home Affairs", Masalah dalam penelitian ini adalah

\footnotetext{
${ }^{5}$ Rian Dwi Hapsari, Kuncoro G Pambayun, and Heri Iman Santoso, "LIBRARY SERVICES FROM HOME ( LSFH ): A Library Policy to Fight Covid-19 in Governance Institute of Home Affairs," INDONESIAN JOURNAL OF LIBRARIANSHIP 1, no. 1 (2020): 1-15.
} 


\section{Erna Fitri Widayati, Pariyanti, Delivery Service Pustakawan Di Era New ...}

terbatasnya layanan perpustakaan daring, komunikasi verbal secara langsung, akses terhadap koleksi rujukan, dan kondisi sumber daya pustakawan, serta beragamnya fasilitas pendukung LSFH yang dimiliki pustakawan. Tujuan penelitian ini adalah menjawab bagaimana kebijakan LSFH yang dilakukan oleh perpustakaan sebagai dukungan untuk memutus rantai penyebaran COVID-19 di IPDN. Metode yang digunakan untuk mengumpulkan data melalui observasi, dokumentasi, dan wawancara daring secara mendalam terhadap 10 orang responden yang terdiri dari 5 orang pustakawan LSFH dan 5 orang penerima layanan LSFH. Hasil penelitian menunjukkan bahwa layanan e-resources menjadi layanan yang paling mudah untuk dilaksanakan dan mengalami peningkatan di masa pandemi COVID-19, layanan publikasi ilmiah memiliki tantangan teknis yang paling besar karena terkendala akses server dan aplikasi, sedangkan layanan bimbingan pemustaka menjadi tantangan terhadap kapabilitas dan kualitas penyampaian informasi seorang pustakawan. Namun secara keseluruhan kebijakan LSFH Perpustakaan IPDN berjalan dengan cukup baik. Selanjutnya penulis memberikan saran untuk peningkatan LSFH ke depan yaitu pemerataan kapasitas ketersediaan bandwidth para pustakawan, peningkatan kapasitas pustakawan, dan perbaikan aplikasi serta server publikasi ilmiah.

Penelitian kedua berjudul "Layanan Perpustakaan Perguruan Tinggi Dalam Menghadapi Pandemi COVID-19"6. Penelitian ini bertujuan untuk mengetahui konsep layanan digital yang dapat dilakukan dan analisis penerapan komunikasi layanan informasi secara online dari perpustakaan perguruan tinggi kepada sivitas akademika. Metode penelitian ini menggunakan metode studi literatur dalam bidang ilmu perpustakaan dan menganalisa beberapa publikasi serta pengamatan yang dilaksanakan perpustakaan selama pandemi berlangsung. Hasil penelitian ini adalah adanya kebutuhan layanan perpustakaan secara online melalui penerapan konsep digital library dan langganan beberapa database $e$ journal, e-book, sebagai bentuk komunikasi layanan informasi dari perpustakaan ke penggunanya. Perpustakaan juga dapat melakukan kerja sama dengan

\footnotetext{
${ }^{6}$ Putut Suharso, Imaniar Putri Arifiyana, and Dewi Wasdiana, "Layanan Perpustakaan Perguruan Tinggi Dalam Menghadapi Abstrak” 4, no. 2 (2020): 271-86.
} 
perpustakaan instansi lain. Layanan perpustakaan dituntut untuk memberikan perubahan dari manual menuju digital saat pandemi berlangsung, oleh sebab itu pustakawan secara otomatis juga dituntut harus meningkatkan kemampuannya supaya dapat menjadi penyebaran informasi.

Penelitian ketiga yang dilakukan oleh David Aju dan Rebecca Ape yang berjudul "Strategis for The Delivery of Library and Information Service To All Nigeria By The Year 2020"7. Tujuan penelitian ini adalah kepuasaan pengguna dalam memperoleh informasi dan bersedia memanfaatkan sumber daya perpustakaan yang telah disebarluaskan. Informasi yang dihasilkan dikemas ulang untuk kepuasan pengguna. Hal ini mengidentifikasi peran profesional pustakawan sebagai fasilitator, penyelenggara, penyebar (disseminators), dan diffusionists. Kegiatannya seperti pengiriman dokumen, literasi informasi, layanan referensi, layanan silang layan, e-resources, dan lainnya. Hasil penelitian ini menyimpulkan bahwa mengabaikan strategi ini bertentangan untuk mencapai perpustakaan dan layanan informasi di tahun 2020 dan merekomendasikan berkolaborasi dengan semua stake holder.

Berdasarkan kajian pustaka tesebut penulis melihat beberapa kesamaan permasalahan terkait layanan perpustakaan di era pandemi COVID-19 antara lain terbatasnya layanan perpustakaan daring/online, terbatasnya sumber daya perpustakaan, layanan yang masih bersifat manual dan fisik, serta kurang optimalnya layanan kepada pemustaka dikarenakan pembatasan akses kunjung perpustakaan selama pandemi. Penulis mengkaji solusi alternatif yang dapat dilakukan perpustakaan selama pandemi COVID-19 masih berlangsung, sehingga layanan informasi kepada pemustaka dapat terus berjalan dan eksistensi pustakawan tidak hilang. Peran aktif pustakawan dalam menyampaikan informasi kepada pemustaka dalam era new normal saat ini sangatlah dibutuhkan salah satunya dengan layanan delivery service.

\footnotetext{
${ }^{7}$ David Aju and Rebecca Ape, "Strategies for the Delivery of Library and Information Services to All in Nigeria by the Year 2020," NASHERJ 9, no. 1 (2020): 53-58.
} 
Erna Fitri Widayati, Pariyanti, Delivery Service Pustakawan Di Era New ...

\section{HASIL PENELITIAN DAN PEMBAHASAN}

\section{Adaptasi kebiasaan baru atau New Normal}

Berbagai negara menerapkan beberapa kebijakan untuk membatasi penyebaran COVID-19. Pemerintah Indonesia mengambil langkah antisipasi untuk meminimalisir dampak dan penularan COVID-19 dengan menerapkan peraturan phisical distancing (menjaga jarak fisik minimal 2 meter), dan diperkuat dengan kebijakan pembatasan sosial berkala besar (PSBB) yang diatur dalam Peraturan Pemerintah No. 21 tahun 2020. Pembatasan tersebut dilakukan untuk mengurangi kerumunan masyarakat dalam jumlah besar yang berpotensi memperbesar penularan virus COVID-19 seperti kegiatan pendidikan/pembelajaran, kegiatan keagamaan, kegiatan di tempat kerja, kegiatan di tempat umum serta kegiatan sosial. Kebijakan tersebut berdampak terhadap berbagai sektor kehidupan, perekonomian menjadi lesu, kegiatan sosial terbatas, pembangunan terhambat,serta pendidikan/pembelajaran pun terkendala. Dalam rangka menjaga stabilitas ekonomi, sosial, politik dan aspek lainnya. Kebijakan ini tidak bisa diberlakukan selamanya, namun bahaya COVID-19 terus mengancam. Oleh karena itu munculah pola hidup baru yang diterapkan oleh masyarakat dengan mengadaptasi kebiasaan baru atau new-normal.

Dikutip dari Kompas.com Ketua Tim Pakar Gugus Tugas Percepatan Penanganan COVID-19 Wiku Adisasmita menyatakan bahwa, new-normal merupakan perubahan dalam menjalankan aktivitas normal namun dengan menerapkan protokol kesehatan untuk mencegah penularan COVID-19 seperti mengurangi kontak fisik dengan orang lain, dan menghindari kerumunan, serta bekerja, bersekolah dari rumah. Perubahan ini perlu dilakukan karena vaksin untuk mengobati virus ini belum ditemukan tetapi kegiatan sehari-hari harus tetap dilaksanakan. Dikutip dalam Tirto.id definisi new-normal menurut Pemerintah Indonesia adalah tatanan baru untuk beradaptasi dengan COVID-19. Cara yang dapat dilakukan untuk beradaptasi dengan COVID-19 adalah dengan menerapkan pola hidup bersih dan sehat pada kegiatan sehari-hari seperti, rajin mencuci tangan menggunakan sabun, menggunakan masker saat keluar rumah, menjaga 
jarak aman dengan orang lain, tidak berkerumun, menjaga kekebalan tubuh dan lainnya.

\section{New-Normal dalam Perpustakaan}

Pandemi global yang saat ini terjadi akibat dari menyebarnya virus COVID-19 berdampak pada perpustakaan sebagai salah satu akses layanan publik. Anjuran pemerintah untuk mengurangi kegiatan di luar rumah mengakibatkan banyak perpustakaan yang menutup layanan fisiknya dan beralih kepada layanan yang berbasis digital/online. Dengan adanya pandemi ini perpustakaan dituntut untuk menjadikan kondisi ini sebagai peluang dan mengembangkan layanannya agar tetap bisa hidup serta pemustaka bisa memanfaatkan koleksinya. Kemampuan setiap perpustakaan berbeda-beda dalam menyikapi kondisi ini, sehingga tidak semua perpustakaan mampu memberikan layanan secara optimal di masa pandemi COVID-19, sehingga mengalami berbagai kendala dalam pemenuhan kebutuhan pemustakanya. Kendala yang dialami perpustakaan selama masa pandemi COVID-19 diantaranya (1) Terbatasnya sumber referensi dan sumber daya yang dimiliki oleh perpustakaan, (2) Kemampuan setiap perpustakaan berbeda-beda dari segi pendanaan, (3) Media atau teknologi yang terbatas, (4) Tidak semua perpustakaan memiliki koleksi digital, (5) Kompetensi pustakawan yang kurang memadai, (6) Ketidaktahuan pemustaka terhadap layanan perpustakaan yang dapat diakses jarak jauh

Dengan adanya kendala tersebut, perpustakaan diharapkan untuk berinovasi dan bertransformasi dalam pelayanan kepada pemustaka. Adapun beberapa hal yang bisa dilakukan oleh perpustakaan selama masa pandemi antara lain:

1. Promosi Perpustakaan Melalui Media Online

Saat ini banyak pemustaka yang membutuhkan akses informasi tetapi terbentur dengan anjuran pemerintah untuk mengurangi aktivitas di luar rumah, oleh karena itu perpustakaan memberikan alternatif menyediakan informasi secara online sehingga pemustaka diberikan kemudahan dalam mendapatkan informasi tanpa harus melanggar protokol kesehatan dari pemerintah. Di sisi 
Erna Fitri Widayati, Pariyanti, Delivery Service Pustakawan Di Era New ...

lain media online atau media sosial dapat dimanfaatkan sebagai sarana untuk mempromosikan layanan perpustakaan. Perpustakaan dapat memanfaatkan media sosial untuk menyebarkan berbagai macam informasi seperti layanan yang ada di perpustakaan, informasi terkait COVID-19, layanan literasi informasi, serta informasi lainnya. Sasaran promosipun tidak hanya bagi sivitas akademika di institusinya saja, tetapi juga bagi masyarakat luas.

2. Mengembangkan Perpustakaan Digital

Selama ini banyak perpustakaan sudah menjadi perpustakaan hybrid yang mana perpustakaan masih memiliki layanan dalam bentuk fisik. Ketika dibenturkan dengan kondisi seperti ini merupakan salah satu peluang bagi perpustakaan dalam membangun maupun mengembangkan perpustakaan digital. Jika perpustakaan sudah memiliki perpustakaan digital maka bisa melakukan perbaikan dan pengembangan baik dari segi kualitas, cara pengoperasian, tampilan, maupun konten seperti menyediakan sumber-sumber informasi dalam bentuk digital atau e-resources agar pemustaka lebih dimudahkan dalam mengakses informasi yang dibutuhkan dimanapun dan kapanpun.

3. Resource sharing atau kerjasama dengan perpustakaan lain

Perpustakaan yang masih mengalami kendala saat menghadapi pandemi ini bisa melakukan kerjasama dengan perpustakaan lain agar layanannya bisa tetap berjalan dan pemustaka bisa mendapatkan akses informasi sesuai dengan yang dibutuhkan. Kerjasama dengan perpustakaan lain dapat berupa tukarmenukar koleksi baik fisik maupun digital, sharing informasi, silang layan, serta kegiatan lainnya. Perpustakaan dapat memanfaatkan jejaring kerjasama antar perpustakaan yang ada di setiap wilayah. Tujuan dari kegiatan ini adalah agar perpustakaan bisa saling membantu dan melengkapi kekurangan informasi maupun sumber daya agar dapat memenuhi kebutuhan pemustaka.

4. Memanfaatkan sumber referensi online gratis

Perpustakaan dapat memanfaatkan sumber referensi online yang dapat diakses secara gratis tanpa harus membeli atau berlangganan. Pemerintah memberikan dukungan sumber referensi digital yang dapat dimanfaatkan 
secara gratis melalui database seperti IOS (Indonesia One Search), eresources.pnri.go.id, sinta.ristekbrin.go.id, garudadikti.go.id maupun e-book dan e-journal lainnya yang gratis dan open acces, selain itu sumber referensi online dapat diakses melalui aplikasi smartphone seperti IJogja, Ijakarta, Ipusnas, serta aplikasi referensi online lainnya.

\section{Delivery Service}

Pembatasan aktivitas di luar rumah yang dianjurkan oleh pemerintah menghambat pemustaka yang ingin mengakses koleksi fisik perpustakaan. Oleh karena itu perpustakaan memberikan alternatif pemanfaatan koleksi dalam bentuk digital. Masalah muncul jika koleksi yang dibutuhkan pemustaka tidak tersedia dalam format digital, di sinilah perpustakaan dapat memberikan layanan delivery service. Layanan delivery service dapat berupa informasi fisik dan digital. Perpustakaan memberikan kemudahan bagi pemustaka yang ingin mengakses koleksi fisik tanpa harus datang langsung ke perpustakaan dengan cara mengantarkan koleksi yang dibutuhkan melalui kurir atau memanfaatkan aplikasi ojek online untuk mengantarkan koleksi yang dibutuhkan ke tempat tinggal pemustaka. Sedangkan informasi digital dapat dikirimkan dengan menggunakan media teknologi komunikasi berbasis online.

\section{Peran Aktif Pustakawan di Era New Normal}

Di era pandemi seperti saat ini menuntut perpustakaan untuk bertransformasi dalam melayani kebutuhan informasi kepada pemustaka tidak terkecuali pustakawan. Adanya kondisi yang menuntut untuk meminimalisir interaksi fisik secara langsung dengan pemustaka berimbas pada sistem tata kelola pelayanan informasi di perpustakaan. Pustakawan harus mencari solusi agar pelayanan di perpustakaan tetap berjalan optimal dan kebutuhan pemustaka dapat terpenuhi.

A.C. Sungkan Hadi sebagaimana dikutip oleh Aat Hidayat ${ }^{8}$ menjabarkan bahwa peran pustakawan sebagai pengelola sumber informasi antara lain:

1. Menyediakan serta mengembangkan koleksi maupun sumber informasi yang

8 Aat Hidayat, "Rekonstruksi Peran Pustakawan Di Era Globalisasi," LIBRARIA: Jurnal Perpustakaan 4, no. 2 (2017): 467, https://doi.org/10.21043/libraria.v4i2.1872. 
Erna Fitri Widayati, Pariyanti, Delivery Service Pustakawan Di Era New ...

komprehensif, mutakhir serta relevan dengan kebutuhan pemustaka. Maka dari itu, pustakawan perlu siaga dengan kebutuhan informasi

2. Melaksanakan pengorganisasian koleksi maupun sumber informasi berdasarkan sistem yang handal termasuk sistem yang berbasis teknologi informasi, agar setiap detail informasi yang dibutuhkan dapat diketahui keberadaannya dan dapat ditemukan dengan cepat, tepat dan akurat.

3. Memandu pemustaka untuk menelusur informasi agar dapat memperoleh informasi sesuai dengan kebutuhannya.

4. Melakukan upaya promosi dan pembinaan minat baca masyarakat, agar melalui pemanfaatan intensif sumber informasi yang ada dapat dibangun serta dikembangkan menjadi masyarakat yang gemar membaca dan gemar belajar (reading and learning society)

5. Melaksanakan upaya-upaya perekaman informasi dan pengetahuan lokal termasuk digitalisasi informasi agar dapat dimanfaatkan secara luas oleh pemustaka.

Dengan adanya peran tersebut jelas tergambar bahwa peran pustakawan tidak hanya mengelola koleksi berupa buku, menata buku di rak, dan melayani pemustaka secara teknis. Namun pustakawan juga berperan dalam pendidikan literasi kepada pemustaka serta menyesuaikan aspek manajerial perpustakaan sesuai dengan kondisi yang ada. Tidak menutup kemungkinan bahwa perpustakaan harus bertransformasi dari layanan konvensional menjadi layanan digital.

Dalam menghadapi era new normal saat ini, pustakawan harus bisa menyelaraskan berbagai macam koleksi/sumber informasi yang ada di perpustakaan dengan perkembangan teknologi informasi. Pustakawan juga perlu menyelenggarakan layanan yang berorientasi dengan kebutuhan dan segala kondisi keterbatasan pemustaka. Sebisa mungkin pustakawan mampu menganalisis kebutuhan informasi pemustaka serta memberikan solusi pelayanan yang bisa diberikan dengan segala keterbatasan yang ada. Adanya pembatasan phisical distancing menuntut pustakawan untuk bergerak maju memberikan solusi 
agar perpustakaan tetap dapat lebih dekat dengan pemustaka meskipun tidak ada interaksi langsung secara fisik.

Pustakawan dituntut untuk lebih kreatif dan inovatif dalam menyajikan sumber informasi. Mekanisme penyajian serta media yang digunakan semestinya lebih memudahkan pemustaka dalam mengakses informasi yang ada sehingga pemustaka tetap dapat merasakan manfaat dan peran perpustakaan meskipun dalam masa pandemi seperti saat ini. Peran aktif pustakawan yang dikelola dengan kreatifitas dan inovasi dapat memberikan nuansa baru terhadap perpustakaan, sehingga eksistensi perpustakaan tidak akan luntur meskipun dalam masa pandemi dan keterbatasan interaksi fisik. Dengan adanya peran aktif tersebut, pemustaka tetap dapat merasakan manfaat perpustakaan sebagai penyedia informasi dan sumber ilmu pengetahuan. Pustakawan juga menjadi lebih dekat dengan pemustaka karena adanya komunikasi yang lebih dekat antara pustakawan dan pemustaka.

Bentuk peran aktif pustakawan untuk beradaptasi pada kebiasaan baru di masa pandemi saat ini dapat diimplementasikan dengan berbagai cara, antara lain:

1. Menyediakan koleksi/sumber informasi yang dapat di akses dengan jarak jauh (digital information)

2. Memberikan layanan daring sebagai pengganti layanan tatap muka.

3. Memberikan kemudahan dalam pelayanan tanpa mempersulit pemustaka

4. Memberikan alternatif sumber referensi ilmu pengetahuan (e-resources) yang dapat di akses secara gratis (free access)

5. Membuat inovasi layanan yang bertujuan memberikan pendidikan literasi informasi kepada pemustaka yang dapat di akses secara online seperti membuat video tutorial pemanfaatan perpustakaan, mengoptimalkan pemanfaatan $e$ resources, serta dapat mengoptimalkan delivery service informasi.

\section{Delivery Service}

Delivery service merupakan salah satu layanan jasa yang dapat diandalkan di dunia bisnis, dan dapat diterapkan di perpustakaan. Delivery service dapat diartikan sebagai layanan antar atau pengiriman informasi dimana produknya 
Erna Fitri Widayati, Pariyanti, Delivery Service Pustakawan Di Era New ...

berupa informasi yang dibutuhkan pemustaka dengan memanfaatkan teknologi sebagai media penghubung antara pustakawan, perpustakaan, dengan pemustaka. Perpustakaan dapat mengadopsi jasa layanan delivery service sehingga pemustaka dapat mengakses informasi perpustakaan secara luring maupun daring. Delivery service di masa pandemi COVID-19 berupa jasa informasi yang dibutuhkan oleh penguna yang dikirimkan oleh pustakawan menggunakan media teknologi dan komunikasi. Teknologi yang digunakan dalam pengiriman dapat berupa media komunikasi seperti email, whatsapp, media sosial, youtube, serta media komunikasi lainnya. Pemustaka dapat melihat dan mengetahui ketersediaan koleksi dengan menelusur melalui OPAC perpustakaan, kemudian menghubungi kontak perpustakaan untuk melakukan pemesanan peminjaman koleksi yang dibutuhkan dan selanjutnya pustakawan akan mengirimkan koleksi yang dibutuhkan ke alamat pemesan. Prosedur dan proses peminjaman sesuai dengan peraturan yang berlaku di perpustakaan. Pemustaka harus mengembalikan koleksi yang dipinjam sesuai batas waktu yang telah ditentukan oleh perpustakaan atau dapat melakukan perpanjangan peminjaman dengan menghubungi petugas.

Dengan adanya layanan delivery service diharapkan pemanfaatan koleksi yang dimiliki perpustakaan baik cetak maupun digital tetap optimal meskipun pemustaka tidak berkunjung ke perpustakaan secara langsung serta dapat memenuhi kebutuhan infomasi bagi pemustaka. Selain delivery service informasi fisik, pemustaka dapat mengajukan kebutuhan informasi secara online, seperti kebutuhan ejournal, ebook, kebutuhan literasi informasi, repository institusi, maupun kebutuhan informasi lainnya. Pemustaka dapat menghubungi petugas perpustakaan untuk mengajukan kebutuhan informasi nya, selanjutnya petugas akan mencarikan informasi yang dibutuhkan untuk selanjutnya mengirimkan kembali informasi tersebut kepada pemustaka.

\section{Komponen Delivery Service}

1. Informasi

Informasi merupakan produk yang akan dilayankan dalam delivery service.

Produk informasi perpustakaan terdiri dari produk fisik dan produk digital. 
Produk informasi fisik di perpustakaan antara lain buku cetak, jurnal cetak, majalah cetak, vcd/dvd, guide book, dan lainnya. Sedangkan produk informasi digital berupa e-journal, e-book, video pembelajaran online, seminar/pelatihan online, video promosi perpustakaan, informasi tentang alur perpustakaan, bimbingan pemustaka berbasis digital, video tutorial perpustakaan, literasi informasi berbasis online, informasi berita online, serta konten berbasis digital lainnya.

2. Pustakawan

Pustakawan berperan sebagai mediator atau perantara antara informasi yang ada di perpustakaan dengan pemustaka. Sebagai mediator informasi pustakawan haruslah memiliki kompetensi di bidangnya. Pustakawan harus mengikuti kemajuan teknologi serta memiliki kemampuan untuk menggunakan teknologi, hal ini sangat penting dalam mendukung peran pustakawan sebagai delivery service informasi. Kompetensi pustakawan yang dibutuhkan antara lain: menguasai teknologi, terampil dalam komunikasi, mengetahui sumbersumber referensi baik cetak maupun digital, memiliki kreativitas dan inovasi untuk menciptakan produk informasi terkini, serta kompetensi lainnya.

3. Media

Media delivery service informasi dapat memanfaatkan teknologi informasi dan komunikasi serta media jasa pengiriman. Media teknologi yang mendukung delivery service seperti media komunikasi email, whatsapp, media sosial, internet, website dan lain sebagainya. Sementara media jasa pengiriman dapat menggunakan jasa kurir, aplikasi ojek online, pos, maupun penyedia jasa lainnya.

4. Pemustaka

Pemustaka dalam delivery service merupakan pihak yang membutuhkan informasi tertentu. 


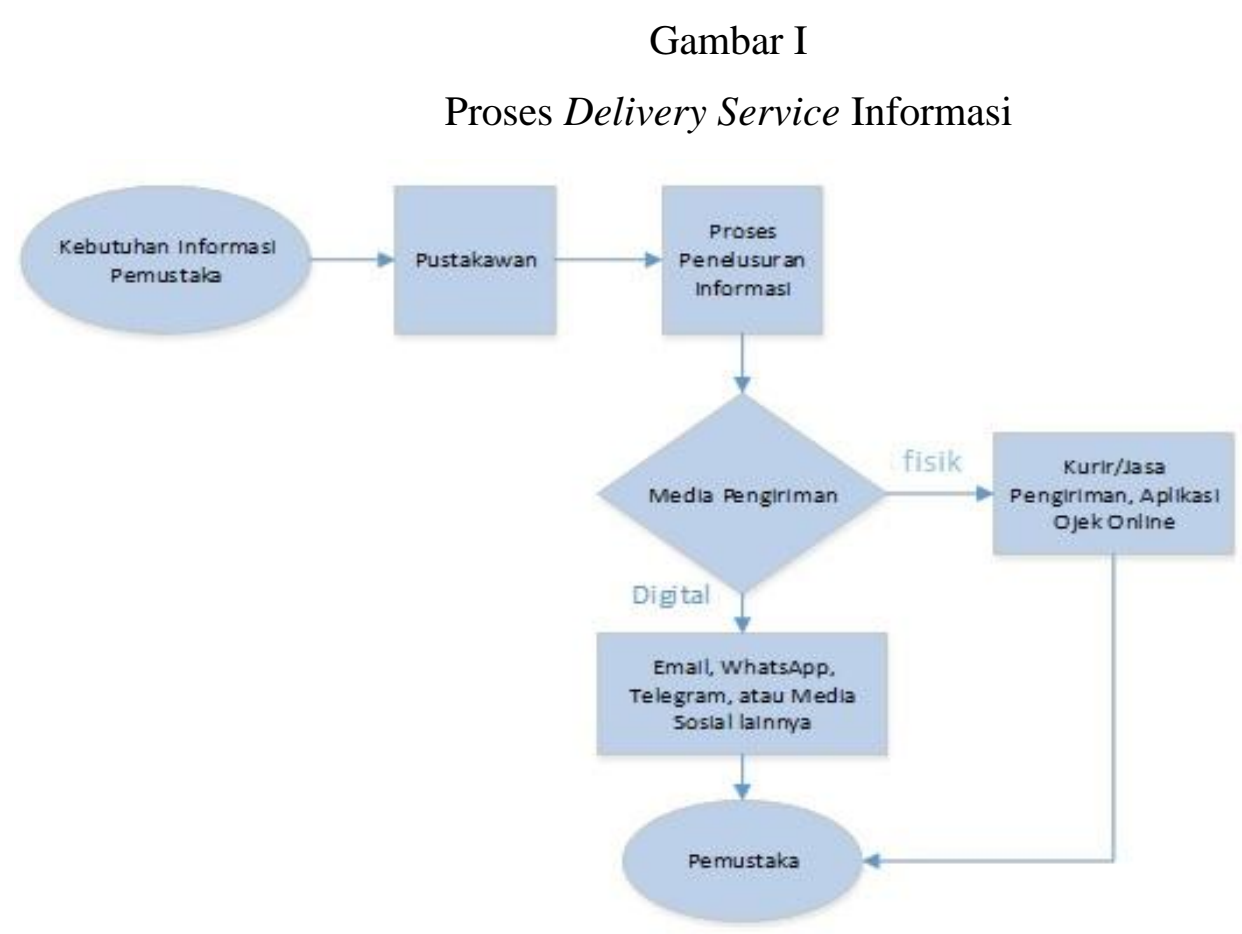

Alur pelayanan delivery service diawali dengan adanya kebutuhan informasi pemustaka. Pustakawan sebagai pengelola informasi merespon kebutuhan informasi pemustaka dengan memberikan produk inovasi informasi perpustakaan sesuai dengan kebutuhan pemustaka. Pustakawan melakukan penelusuran informasi melalui sumber daya perpustakaan yang tersedia baik cetak maupun digital. Setelah pustakawan mendapatkan informasi yang dibutuhkan pemustaka, maka proses dapat dilanjutkan dengan mengirimkan informasi tersebut melalui media pengiriman berbasis fisik dan online. Kebutuhan informasi berupa dokumen fisik dapat dikirimkan melalui jasa pengiriman kurir, pos, maupun ojek online sesuai dengan kesepakatan biaya pengiriman dengan pemustaka. Pelayanan delivery service informasi fisik dilakukan dengan tetap berpedoman pada peraturan perpustakaan dan menerapkan protokol kesehatan untuk meminimalisir penyebaran COVID-19. Sedangkan delivery service dalam format digital dapat dikirimkan melalui email, whatsapp, telegram, website, instagram, facebook, youtube, serta media berbasis digital lainnya.

Delivery service informasi menjadi solusi alternatif utama layanan perpustakaan di era pandemic, sehingga dapat meningkatkan kulitas layanan perpustakaan menjadi lebih optimal, dan menjangkau seluruh pemustaka yang 
terdampak COVID-19. Implementasi layanan perpustakaan berupa delivery service tidak akan berjalan dengan optimal tanpa adanya implementasi teknologi informasi yang memadai, kemampuan pustakawan yang memadai, regulasi layanan yang tidak berbelit, kerjasama dengan perpustakaan atau penyedia informasi lain dengan resource sharing, serta kolaborasi dengan penyedia jasa lain seperti jasa pengiriman. Penerapan delivery service informasi di perpustakaan memberikan manfaat antara lain memberikan kemudahan pemustaka memperoleh informasi yang dibutuhkan baik cetak maupun digital, meningkatkan pemanfaatan koleksi perpustakaan, meningkatkan kepuasan pemustaka, membantu pemustaka mendapatkan informasi terkini secara efektif dan efisien, memacu perpustakaan dan pustakawan untuk berinovasi dengan membuat dan menyajikan informasi dalam format baru, mengoptimalkan kolaborasi pustakawan dengan penyedia informasi lain, serta meningkatkan citra positif perpustakaan dan pustakawan oleh masyarakat.

\section{PENUTUP}

\section{Simpulan}

Berdasarkan penjelasan yang telah dibahas tersebut dapat ditarik kesimpulan bahwasannya:

1. Peran aktif pustakawan di era new normal sangat penting, salah satunya dengan inovasi layanan delivery service informasi, agar pemenuhan kebutuhan informasi pemustaka dapat terfasilitasi meskipun terkendala jarak fisik.

2. Di masa pandemi COVID-19, Perpustakaan dapat bertransformasi dari layanan fisik ke layanan digital dengan memanfaatkan berbagai sumber referensi online yang dapat diperoleh melalui pengembangan perpustakaan digital, mengoptimalkan resource sharing dari kerjasama antar perpustakaan, memanfaatkan sumber referensi online yang gratis, serta melaksanakan layanan secara efektif dan efisien.

3. Layanan delivery service informasi bermanfaat untuk meningkatkan layanan perpustakaan menjadi efektif dan efisien, memacu perpustakaan dan 
Erna Fitri Widayati, Pariyanti, Delivery Service Pustakawan Di Era New ...

pustakawan untuk berinovasi dengan membuat dan menyajikan informasi dalam format baru, mengoptimalkan kolaborasi pustakawan dengan penyedia informasi lain, serta meningkatkan citra positif perpustakaan dan pustakawan oleh masyarakat. Delivery service merupakan layanan pengiriman informasi, dimana produknya berupa informasi yang dibutuhkan pemustaka, dengan menggunakan teknologi sebagai media penghubung. Produk yang dilayankan terdiri dari produk informasi fisik dan digital. Delivery service informasi di era new normal dapat dilakukan dengan dua cara yaitu pengiriman koleksi secara fisik dan informasi digital. Pengiriman informasi fisik menggunakan jasa pengiriman maupun aplikasi ojek online dengan tetap memperhatikan protokol kesehatan, sedangkan layanan delivery service informasi digital dapat dilakukan menggunakan media komunikasi digital seperti email, whatsapp, telegram, instagram, youtube, aplikasi komunikasi video, serta media komunikasi berbasis digital lainnya.

\section{Saran}

Pertama, bagi pemerintah agar lebih serius dalam mengimplementasikan pengembangan perpustakaan digital, meningkatkan sarana akses referensi digital agar menjangkau keseluruh penjuru negeri.

Kedua, kepada pimpinan institusi dan pemangku kebijakan agar mengoptimalkan dukungan kebijakan pengembangan perpustakaan serta dukungan dana untuk pengembangan perpustakaan berbasis digital.

Ketiga, kepada kepala perpustakaan untuk meningkatkan kualitas implementasi program perpustakaan digital seperti penguatan konsep dan perancangan, pengembangan akses koleksi secara terbuka, manajemen sumber daya manusia professional, penyusunan akses dan regulasi akses informasi.

Keempat, bagi pustakawan, para pemerhati dan ahli dibidang perpustakaan, agar hasil penelitian ini dapat dijadikan dasar pengembangan inovasi lain untuk meningkatkan layanan perpustakaan berbasis online yang banyak keterbatasan baik dari anggaran, sarana akses, maupun kemampuan literasi informasi pemustaka dalam memanfaatkan referensi online. 


\section{Pustakaloka: Zurnal Kajian 2nformasi dan Perpustakaan}

Volume 12 No. 2, Desember 2020

\section{DAFTAR RUJUKAN}

Aju, David, and Rebecca Ape. "Strategies for the Delivery of Library and Information Services to All in Nigeria by the Year 2020." NASHERJ 9, no. 1 (2020): 53-58.

Hapsari, Rian Dwi, Kuncoro G Pambayun, and Heri Iman Santoso. "LIBRARY SERVICES FROM HOME ( LSFH ): A Library Policy to Fight Covid-19 in Governance Institute of Home Affairs." INDONESIAN JOURNAL OF LIBRARIANSHIP 1, no. 1 (2020): 1-15.

Hidayat, Aat. "Rekonstruksi Peran Pustakawan Di Era Globalisasi." LIBRARIA: Jurnal Perpustakaan 4, no. 2 (2017): 467. https://doi.org/10.21043/libraria.v4i2.1872.

Indonesia. Undang-Undang Republik Indonesia Nomor 43 Tahun 2007 Tentang Perpustakaan (2007).

Kementerian Komunikasi dan Informatika RI. Undang-Undang Republik Indonesia Nomor 14 Tahun 2008 tentang Keterbukaan Informasi Publik (2008).

Purwono. Dokumentasi. Yogyakarta: Graha Ilmu, 2010.

Suharso, Putut, Imaniar Putri Arifiyana, and Dewi Wasdiana. "Layanan Perpustakaan Perguruan Tinggi Dalam Menghadapi Abstrak" 4, no. 2 (2020): 271-86.

WHO. "WHO Coronavirus Disease (COVID-19) Dashboard." https://covid19.who.int/, 2020. 